\title{
Tariff policy and investment support for the modernization of the public utility infrastructure of the municipality
}

\author{
Evgeny Balashov ${ }^{1}$ and Ariadna Kirillova ${ }^{2, *}$ \\ ${ }^{1}$ Moscow Analytical Center in the Field of Urban Economy, 13/1 Filippovsky pereulok, Moscow, \\ 119019, Russia \\ ${ }^{2}$ Higher School of Economics University, 20 Myasnitskaya Ulitsa, Moscow, 101000, Russia
}

\begin{abstract}
At the present stage, it becomes relevant to search for a new model of tariff formation in the housing and communal services (HCS) in accordance with the scale and significance of restructuring the economy and the conditions of functioning during a pandemic, as well as effective mechanisms for regulating tariffs and reducing the cost of production and provision of services. Despite the progress in improving the tariff policy, determined by the long-term period of the formation of parameters for changing the regulated tariffs and the use of the existing multi-level system of social protection of the population when paying for housing and communal services in the regulation of prices for the organizations of the communal complex, the expansion of methodological approaches to the regulation of tariff policy, the existing system of social protection of the population when paying for housing and communal services, the availability of information on the activities of regulated organizations, the task of accelerating the growth of the Russian economy and the sustainable functioning of housing and communal services dictate the need to consider tariff policy as one of the tools of resource efficiency and find additional sources of funding. The problems systematized in the article require decision-making to eliminate them at the state, regional and municipal levels. The necessity of combining a significant number of separate sectoral documents on the communal sector into a single federal law has been proved, which will regulate and establish unified regulatory and methodological principles for the formation of tariffs and will make this process more transparent. The paper discusses the problems of increasing the importance of the share of the investment component in the tariffs for utilities, as well as factors such as deductions from profits (with their financial stability), raising borrowed funds, selling bonds and systematic audit of their production and economic activities, increasing the transparency of costs.
\end{abstract}

*Corresponding author: kirillova_an@mail.ru 


\section{Introduction}

The tasks set to accelerate the growth of the Russian economy and the sustainable functioning of the housing and communal services (HCS) dictate the need to consider tariff policy as one of the tools for solving the problems of increasing productivity, overcoming the technological backwardness of infrastructure organizations and consumers of their services (environmental friendliness, energy efficiency, modernization, innovative development, etc.).

The tariff policy in the field of HCS is the activity of the state to regulate the establishment of a specific level of tariff in the regions of the Russian Federation, to determine the surcharges to the tariff, to develop long-term and operational management of tariff changes in the activities of enterprises, taking into account the market conditions. An important progress that contributes to investment activity is the transition from annual substantiation of the value of tariffs for resource supplying organizations to long-term regulation based on methods for calculating economically justified costs (expenses); indexation of established tariffs, return on invested capital and comparison of analogues.

Studies have shown that among modern Russian scientists, the regulation of the organization of state policy in the field of HCS and the establishment of tariffs are considered in the works of the following authors: Dolmatov I.A., Kazakov V.V., Kirillova A.N., Koval V.N., Kondratieva M.N., Korzhov V.Yu., Petruseva N.A., Rozov D.V., Silin Ya.P., Stukalov A.V., Syuzeva T.A., Trukhina N.I., Fedoskina L.A., Chernyshova L.N. and others [10, 12, $14,19]$.

However, some issues of methodology and practice of tariff regulation and investment support for the activities of public utilities organizations to accelerate the processes of renovation and modernization of engineering systems require further research of resource efficiency mechanisms and the search for additional sources of funding.

The purpose of this study was to substantiate the methods of investment support for the modernization of the existing public utility infrastructure at the expense of the own resources of the organizations of the communal complex, including increasing the importance of the investment component in tariffs for utilities, finding reserves for attracting own funds to finance the acceleration and growth of the volume of renovation of engineering systems.

\section{Materials and methods}

The principles of tariff regulation are related to the peculiarities of resource supplying organizations in the field of heat supply, water supply and sewerage, electricity and gas supply, which include the technology of production that is strictly tied to the territory in which they are located. As a result, all enterprises of the listed sub-sectors of the utilities sector are natural local monopolies, which affects the substantive dispersion of methodological approaches to the formation of management systems for the development of public utility infrastructure and regulation of tariffs, the fragmentation of the sectoral approach to the rates and resource indicators of expanded reproduction. In practice, this is expressed in the imbalance of financial flows in the life cycle of facilities, the use of residual approaches to resource allocation and indicates, in general, an extensive type of development and functioning of the public utility infrastructure [7-13].

The level of resource provision for the modernization of the public utility infrastructure is determined by the planned level and rate of financial filling of investment programs carried out by the organizations of the communal complex. Resource management of the aggregate of strategically important projects for the modernization of communal infrastructure is the maximum possible provision of the planned deadlines for the required work and the acceleration of financial flows for the renovation of facilities that are not provided with repair 
measures during operation, which have high physical wear and low investment attractiveness [14-16].

Analyzing the transformations of tariff regulation that took place from the beginning of market reforms to the present day, the following main achievements in the field of tariff policy can be noted: the long-term nature of the formation of parameters and the rate of change of regulated tariffs at the macro level; the introduction of a long-term tariff policy in price regulation for organizations of the communal complex as a factor ensuring the demand and availability of utilities and as a source of the investment component in the tariff for financing the modernization of utilities infrastructure; an operating multi-level system of social protection of the population when paying for utility bills; expanding the methodological tools for regulating tariff policy; availability of information on the activities of regulated organizations and regulators [20].

However, despite the efforts of regulators and the presence of certain successes, current main problems of state policy in the field of tariff setting are the following and presented in Table $1[9,16]$.

Table 1. Problems of tariff setting in the field of public utility infrastructure.

\begin{tabular}{|c|c|c|}
\hline Problems & Reasons & Consequences \\
\hline $\begin{array}{l}\text { Imperfection of } \\
\text { the legal } \\
\text { framework }\end{array}$ & $\begin{array}{l}\text { Lack of a single normative act: } \\
\text { regulation of tariff setting includes } 18 \\
\text { federal laws, more than } 40 \text { resolutions } \\
\text { of the Government of the Russian } \\
\text { Federation, more than } 100 \text { departmental } \\
\text { regulatory legal acts }\end{array}$ & $\begin{array}{l}\text { It becomes difficult to understand } \\
\text { the tariff regulation scheme, } \\
\text { litigation arises, state regulation of } \\
\text { tariff formation processes becomes } \\
\text { more complicated }\end{array}$ \\
\hline $\begin{array}{l}\text { Using standards } \\
\text { instead of } \\
\text { calculating actual } \\
\text { resources } \\
\text { consumed }\end{array}$ & $\begin{array}{l}\text { Lack of equipping with measuring } \\
\text { devices and control over the } \\
\text { consumption of communal resources by } \\
\text { consumers, low interest of all } \\
\text { participants in the production process, } \\
\text { provision and consumption of } \\
\text { communal resources in their efficient } \\
\text { use and energy saving }\end{array}$ & $\begin{array}{l}\text { The loss of a significant amount of } \\
\text { utility resources during their } \\
\text { transportation, but the payment for } \\
\text { them is still included in the final } \\
\text { tariff }\end{array}$ \\
\hline $\begin{array}{l}\text { High wear and } \\
\text { poor condition of } \\
\text { utilities }\end{array}$ & $\begin{array}{l}\text { Saving on the quality of construction } \\
\text { and repair of utilities }\end{array}$ & $\begin{array}{l}\text { Loss of a significant amount of } \\
\text { utility resources in the process of } \\
\text { their transportation, rise in tariffs }\end{array}$ \\
\hline $\begin{array}{l}\text { Availability of } \\
\text { cross- } \\
\text { subsidization }\end{array}$ & $\begin{array}{l}\text { Artificial understatement of tariffs for } \\
\text { the population due to their } \\
\text { overstatement for industrial enterprises }\end{array}$ & $\begin{array}{l}\text { Conflict of interests of the state, } \\
\text { management companies and the } \\
\text { population }\end{array}$ \\
\hline $\begin{array}{l}\text { Lack of } \\
\text { profitability of } \\
\text { resource } \\
\text { supplying } \\
\text { companies and } \\
\text { the state }\end{array}$ & $\begin{array}{l}\text { The rise in tariffs and the lack of income } \\
\text { among the population leads to non- } \\
\text { payment of utility bills }\end{array}$ & $\begin{array}{l}\text { The rise in prices for resources for } \\
\text { the population, the lack of } \\
\text { economic interest of resource } \\
\text { supplying and communal } \\
\text { enterprises to increase the } \\
\text { efficiency of their activities }\end{array}$ \\
\hline $\begin{array}{l}\text { Inaccessibility of } \\
\text { utilities for some } \\
\text { consumer groups }\end{array}$ & $\begin{array}{l}\text { Despite the use of the "costs +" method, } \\
\text { prices for services continue to rise, and } \\
\text { there is an insufficiency and low quality } \\
\text { of services provided in rural settlements. }\end{array}$ & $\begin{array}{l}\text { Problems of resource supply } \\
\text { companies with debts and } \\
\text { problems of the population with } \\
\text { power outages }\end{array}$ \\
\hline
\end{tabular}

All these problems require decision-making to eliminate them at the state, regional and municipal levels. An effective state policy in the field of managing tariffs in housing and communal services is possible only with the modernization of private and public infrastructure by providing funds from the budgets, as well as attracting private investment and providing guarantees from the state for investment. 
To solve the problem of tariff setting, it is necessary to improve the regulatory and legal framework, which is complicated by a large number of industry documents, which makes it difficult to understand the tariff regulation scheme and gives rise to the problem of imperfect legal framework. $[1,2,3,4,5,6]$. It is necessary to combine these documents into a single federal law, which will regulate this communal sphere, establish uniform principles for the formation of tariffs and make this process more transparent.

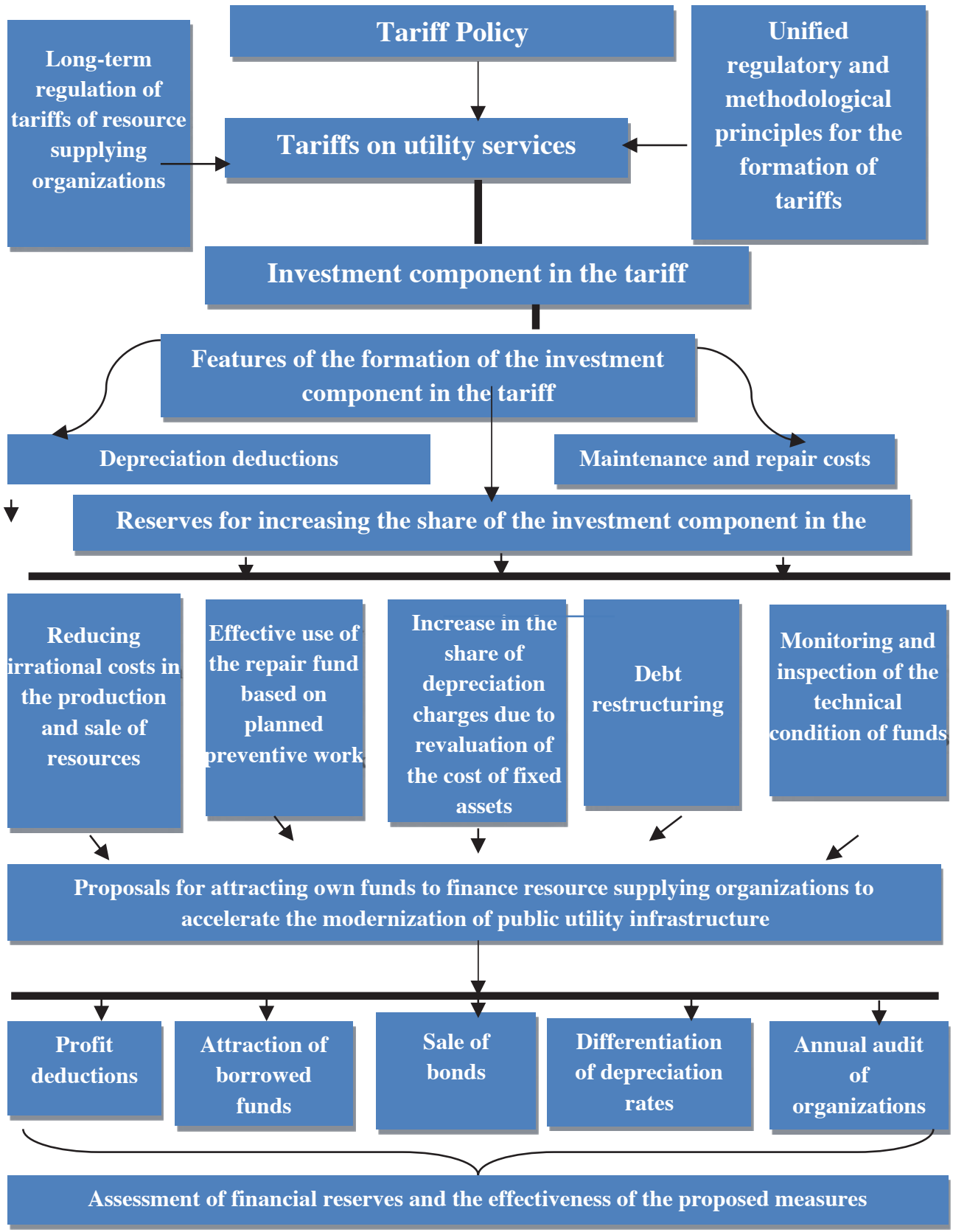

Fig. 1. Structural and methodological diagram of increasing the share of own funds of resource supplying organizations as a source of financing for the modernization of public utility infrastructure 
The key task should be the further improvement of methodological approaches to incentive tariff regulation and the introduction of advanced innovative technologies.

It is important to solve the problem of increasing the importance in tariffs for utilities of the level of the investment component, as an element of the own funds of resource supplying organizations and the most important factor in investment support for the modernization of utilities infrastructure. The need to increase the share of the investment component in tariffs is associated with a very poor repair of communal infrastructure facilities, the volumes of which were growing in the retrospective period, but even in modern conditions, the annual volumes of modernization do not reach the normatively required indicators. The investment component is formed at the expense of depreciation and costs for maintenance and scheduled preventive current and capital repairs.

There is an urgency of the practical realization of the potential and the identification of reserves for their maximum use in order to increase the rate of financial filling of investment programs carried out by organizations of the communal complex at their own expense. First of all, it is required to take measures to increase depreciation funds in the investment component based on the revaluation of the cost of fixed assets that are currently undervalued. This may lead to an increase in tariffs. However, due to the reorientation of the share of expenses for maintenance and overhaul of equipment for investment purposes, including the modernization of facilities, increasing resource efficiency and reducing non-productive costs, it is possible to achieve a reduction in the cost of production and sale of utilities without a significant increase in tariffs. $[15,18]$. The reserves for increasing the share of the investment component in the tariff are the reduction of irrational costs in the production and sale of services, the effective use of the repair fund for the purposes of scheduled preventive maintenance, an increase in the share of depreciation deductions based on the revaluation of the cost of fixed assets, monitoring the results of surveys of the technical condition of utility infrastructure facilities. The structural and methodological scheme for increasing the share of own funds of resource-supplying organizations as a source of financing for the modernization of public utility infrastructure is shown in Fig. 1.

\section{Results}

A comprehensive combination of jointly implemented measures to improve the methodology and practice of revaluation of fixed assets, taking into account the assessment of the technical condition and increasing production efficiency by reducing operating costs within the framework of resource saving programs, optimizing the number of personnel, introducing innovative technologies to increase productivity, creating a repair fund with an indication in the accounting the policy of organizing the purposes of its use will increase the share of the investment component in the tariff, according to experts, up to $10-15 \%$ and direct it to investment purposes.

\section{Discussion}

Challenges caused by geopolitical problems and the pandemic can affect the deterioration of the situation of infrastructure organizations due to the projected decline in business activity and the volume of activities of a significant number of organizations, as well as with a possible increase in costs. This requires adjusting the investment programs of utility companies and finding financial reserves in the face of the need to curb tariff growth at the expense of utilities' own funds by increasing the share of the investment component in the tariff by increasing the amount of depreciation deductions and the formed repair fund for the purposes of scheduled preventive maintenance, as well as resource efficiency mechanisms and other proposed measures. In the proposed unified federal law on regulation of the 
communal sector, which establishes uniform principles for the formation of tariffs, it is advisable to include mechanisms for stimulating regulation of resource efficiency and implementation of investment programs.

\section{Conclusions}

At the same time, reserves for the growth of indicators of the investment component in the tariff should be identified, which can be ensured by reducing irrational costs in the production and sale of resources, focusing the repair fund for modernization, revaluating fixed assets based on a survey of their technical condition in order to increase depreciation deductions, debt restructuring, etc. At the same time, the organizations of the communal complex can use their own funds for modernization due to the deductions from profits (with their financial stability), attracting borrowed funds, selling bonds, as well as systematically conducting an audit of their production and economic activities, increasing the transparency of costs.

\section{References}

1. Federal Law No. 35-FZ of 26.03.2003 "On Electric Power Industry".

2. Federal Law No. 416-FZ of 07.12.2011 "On Water Supply and Sanitation".

3. Federal law dated 31.03.1999 № 69-FZ "On gas supply in the Russian Federation"

4. Federal law of 27.07.2010 No. 190-FZ "On heat supply".

5. Federal law of 17.08.1995 No. 147-FZ "On natural monopolies"

6. Federal law of 06.10.2003 №131-FZ "On General principles of organization of local self-government in the Russian Federation»

7. Strategy for the development of housing and communal services in the Russian Federation for the period up to 2020: Order of the Government of the Russian Federation, $80(26.01 .2016)$

8. Ya. P. Silin, G. V. Astratova, et al., Housing and communal services and quality of life in the XXI century: economic models, new technologies and management practices: collective, 600 (monogr. Russia, Moscow, Ekaterinburg: Publishing center "science of Science", 2017)

9. I. Zolotova, Cross-subsidization in the electric power industry: empirical analysis, evaluation of the efficiency of own generation. Strategic decisions and risk management, (3)70-77 (2017)

10. V. V. Kazakov, Questions of implementation of the balanced tariff policy in housing and communal services Journal "Bulletin of Tomsk State University" (2009)

11. E. R. Kalimullina, N. G. Iraeva, Housing and communal services and its role in the development of the housing and communal services market, Vestnik UGAES. Science, education, and economics. Series: Economics, 1(7), 137-141 (2014)

12. V. N. Koval, Directions for improving the sphere of housing and communal services. City management: theory and practice, 2 (2015)

13. Fundamentals of pricing in housing and communal services. Under the general editorship of Prof., L. N. Chernyshova JSC " PC "Orius", 542 (2013)

14. D. V. Rozov, Analysis of the impact of depreciation policy on the effective renewal of fixed capital JOURNAL of Economic Analysis: theory and Practice (2011)

15. T. A. Syuzeva, Methods of regulating the investment component of utility tariffs. Journal of Russian Entrepreneurship (2009) 
16. Tariffs and standards of housing and communal services for the population. Legal regulation: Reference Manual-Moscow: State Duma Edition (2011)

17. V. M. Tereshchenko, Investment policy of the region as a component of the state investment policy Materials of the X All-Russian Scientific and practical Conference "State, Power, Management and Law" Moscow November 27, 262-264 (2019)

18. V. P. Tokmakov, V. R. Avanesyan, Investment opportunities of housing and communal services, modernization of municipal infrastructure facilities. http://www.bdo.ru/ (Last accessed 09.12.2020)

19. A. V. Chernyshov, Methodological approach to the development of complex measures that ensure sustainable reproduction of municipal infrastructure objects. Management $\mathbf{3}$, 43-47 (2016)

20. E. V. Yarkin, I. A. Dolmatov, Tariff policy in the Russian Federation in the branches of the municipal sphere: priorities, problems, prospects [Text] : dokl. k XXI Apr. international scientific conference on problems of economic and social development, Moscow, 2020, Nats. research.u-t "Higher School of Economics", 174 (Moscow, Publishing House of the Higher School of Economics, 2020) 